Pesq. Vet. Bras. 36(8):701-704, agosto 2016 DOI: $10.1590 / \mathrm{S} 0100-736 \mathrm{X} 2016000800004$

\title{
Characterization of Streptococcus suis through serotyping, SE-AFLP and virulence profile ${ }^{1}$
}

\author{
Franco F. Calderaro ${ }^{2}$, Luisa Z. Moreno², Daniela S. Doto², Carlos E.C. Matajira², Vasco \\ T.M. Gomes ${ }^{2}$, Thais S.P. Ferreira², Renan E. Mesquita ${ }^{2}$ and Andrea M. Moreno ${ }^{2 *}$
}

\begin{abstract}
Calderaro F.F., Moreno L.Z., Doto D.S., Matajira C.E.C., Gomes V.T.M., Ferreira T.S.P., Mesquita R.E. \& Moreno A.M. 2016. Characterization of Streptococcus suis through serotyping, SE-AFLP and virulence profile. Pesquisa Veterinária Brasileira 36(8):701-704. Laboratório de Sanidade Suína e Virologia, Faculdade de Medicina Veterinária e Zootecnia, Universidade de São Paulo, Av. Prof. Dr. Orlando Marques de Paiva 87, Cidade Universitária, São Paulo, SP 05508-270, Brazil. E-mail: morenoam@usp.br

Streptococcus suis is one of most important pathogens in the swine industry worldwide. Despite its importance, studies of $S$. suis characterization in South America are still rare. This study evaluates S. suis isolates from distinct Brazilian states, from 1999 to 2004, and its molecular and serological characterization. A total of 174 isolates were studied. S. suis identification was confirmed by PCR and isolates were further serotyped and genotyped by SE-AFLP and amplification of virulence markers. Serotype 1, 2, 3, 4, 7, 18, 22 and 32 were identified among the studied isolates, and only $4 \%$ were characterized as non-typeable. The $\mathrm{mrp}^{+} / \mathrm{epf} \mathrm{f}^{+} / \mathrm{sly}^{+}$genotype was the most frequent. The SE-AFLP analysis resulted in 29 patterns distributed in three main clusters with over $65 \%$ of genetic similarity. Isolates presented a slight tendency to cluster according to serotype and origin; however, no further correlation with virulence genotypes was observed.
\end{abstract}

INDEX TERMS: Streptococcus suis, serotyping, SE-AFLP, genotype, virulence genes.

RESUMO.- [Caracterização de Streptococcus suis por sorotipagem, SE-AFLP e perfil de virulência.] Streptococcus suis é um dos patógenos de maior importância para indústria suinícola mundial. Apesar de sua importância, a caracterização de isolados de $S$. suis na América do Sul ainda é pouco descrita. 0 presente estudo descreve a avaliação de isolados de $S$. suis provenientes de diferentes Estados brasileiros, e sua caracterização sorológica e molecular. Foram avaliados 174 isolados de $S$. suis e os mesmos foram submetidos a SE-AFLP e pesquisa de marcadores de virulência. Os sorotipos 1, 2, 3, 4, 7, 18, 22 e 32 foram identificados dentre os isolados estudados e apenas $4 \%$ foram caracterizados como não tipáveis. 0 perfil de virulência $\mathrm{mrp}^{+} / \mathrm{epf}^{+} / \mathrm{sly}^{+}$foi o mais frequente. A análise do SE-AFLP resultou em 29 perfis distribuídos em três grupos principais com mais de $65 \%$ de similaridade genética. Os isolados apresentaram tendência

\footnotetext{
${ }^{1}$ Received on July 4, 2015.

Accepted for publication on May 6, 2016.

${ }^{2}$ Laboratório de Sanidade Suína e Virologia, Faculdade de Medicina Veterinária e Zootecnia (FMVZ), Universidade de São Paulo (USP), Av. Prof. Dr. Orlando Marques de Paiva 87, Cidade Universitária, São Paulo, SP 05508 270, Brazil. *Corresponding author: morenoam@usp.br
}

de se agrupar segundo origem e sorotipo; no entanto, não foi observada correlação entre os grupamentos e os perfis de virulência.

TERMOS DE INDEXAÇÃO: Streptococcus suis, sorotipagem, SE-AFLP, genótipo, genes de virulência.

\section{INTRODUCTION}

Streptococcus suis is one of most important pathogens in the swine industry worldwide. The infection is characterized by meningitis, arthritis, endocarditis, septicemia and pneumonia during farrowing, post-weaning and growing stages (Gottschalk et al. 1989). Until now, 35 serotypes have been described, although serotype 2 is the one most associated with pig infection (Goyette-Desjardins et al. 2014). It is also considered an emerging zoonosis and can be transmitted to humans by direct contact with diseased or carrier swine and even by derived products (Gottschalk et al. 2007).

Virulence markers have already been associated with clinical isolates, serotypes and disease outcome. The most studied virulence factors are suilysin (SLY; sly), muramidase-released protein (MRP; $m r p$ ) and extracellular factor (EF; epf) (Vecht et al. 1992, Jacobs et al. 1994). Regardless 
that the $\mathrm{mrp}^{+} / \mathrm{epf}^{+} / \mathrm{sly}^{+}$genotype is the most prevalent worldwide, it has already been suggested a correlation between the $\mathrm{mrp}^{+} / \mathrm{epf}^{+} / \mathrm{sly}^{+}$genotype with clinical human and porcine isolates (Silva et al. 2006, Wei et al. 2009).

Despite its importance, studies of $S$. suis characterization in South America are still rare. Here we present the evaluation of $S$. suis isolates from distinct Brazilian states, during the period of 1999 to 2004, and its molecular and serological characterization.

\section{MATERIALS AND METHODS}

Streptococcus suis was isolated from 135 animals originating from 109 herds located in the Brazilian states of São Paulo, Santa Catarina, Paraná, Pernambuco, Bahia, Minas Gerais, Goiás and Rio Grande do Sul. A total of 174 isolates were obtained from pigs with clinical manifestation of meningitis, septicemia, arthritis or pneumonia from 1999 to 2004. Samples were plated on Columbia blood agar base containing $5 \%$ of sheep blood supplemented with SR-126 (Oxoid Ltd, Cambridge/UK). Bacteriological identification was based on: presence of $\alpha$-hemolysis on blood agar, negative Voges-Proskauer test, amylase production, inulin and trehalose fermentation, and lack of mannitol and sorbitol fermentation. Presumptive $S$. suis isolates were directed for species confirmation by PCR and serotyping.

Genomic DNA was extracted as described by Boom et al. (1990) and $S$. suis identification was confirmed with the $g d h$ gene amplification using Okwumabua et al. (2003) primers. The $m r p$, epf and sly virulence genes were also amplified as previously described by Wisselink et al. (2002) and King et al. (2001). Isolates were tested for the $35 \mathrm{~S}$. suis serotypes by the coagglutination test (Gottschalk et al. 1989).

The SE-AFLP was performed following McLauchlin et al. (2000) protocol. DNA fragments were detected through electrophoresis at $24 \mathrm{~V}$ for $26 \mathrm{~h}$ in $2 \%$ agarose gel stained with BlueGreen ${ }^{\circledR}$ (LGC Biotecnologia, São Paulo, Brazil). The 100 bp DNA Ladder (New England BioLabs Inc., Ipswich, MA, USA) was used for molecular weight determination. Fingerprint patterns were analyzed by comprehensive pairwise comparison through Dice coefficient and the respective mean values were employed in UPGMA, using BioNumerics 7.5 (Applied Maths NV, Sint-Martens-Latem, Belgium) to construct a dendrogram. Similarity value of $90 \%$ cut-off was used for SE-AFLP cluster analysis (Van Belkum et al. 2007).

\section{RESULTS AND DISCUSSION}

Serotype 2 presented the highest frequency among Streptococcus suis isolates studied (77\%), followed by serotypes 1 (8\%), $3(6 \%), 7(2 \%)$ and $18(2 \%)$. The serotypes 4, 22 and 32 were identified in only one isolate each (1\%). Only 6 $(4.0 \%)$ of studied isolates were characterized as non-typeable (NT). The origin of $S$. suis strains and the distribution of serotypes according the State and isolation site is presented in Table 1 and Figure 1.

From the 174 studied strains, 61.5\% were isolated from central nervous system, $21.3 \%$ from the respiratory tract, and $16.1 \%$ from joint, peritoneum, pericardium/heart and blood samples. Among the 37 strains from the respiratory tract, only three of them originated from nasal cavity swabs of healthy carrier animals and were considered as non-invasive isolates; the remaining were isolated from lung and thoracic cavity samples of diseased animals.
The combination of mrp, epf and sly genes resulted in nine genotypes (Table 2). The $\mathrm{mrp}^{+} / \mathrm{epf}^{+} / \mathrm{sly}^{+}$genotype was the most frequent $(42.5 \%)$ and only $11.5 \%$ of $S$. suis isolates were negative for the studied virulence genes. The epf gene presented fragment size variation (epfv) with amplicons of 1278, 1505, 2313, 1537 and 2993 bp.

The SE-AFLP analysis resulted in 29 patterns (A1 - A29) distributed among three main clusters with over $65 \%$ of genetic similarity (Fig.2). Isolates presented a slight ten-

Table 1. Distribution of Streptococcus suis isolates according to states of origin, serotypes and isolation sites

\begin{tabular}{lccc}
\hline State* & $\begin{array}{c}\text { Number of } \\
\text { strains (\%) }\end{array}$ & Isolation sites & $\begin{array}{c}\text { Serotypes } \\
\text { (Number of strains) }\end{array}$ \\
\hline PE & $1(0.6)$ & Nasal cavity & $2(1)$ \\
BA & $2(1.2)$ & CNS & $2(2)$ \\
RS & $7(4.0)$ & CNS, heart & $2(7)$ \\
GO & $8(4.6)$ & Lung, nasal cavity & $18(3), 22(1)$, \\
& & & $32(1)$, NT (3) \\
PR & $10(5.7)$ & CNS, lung & $2(9), 3(1)$ \\
MG & $22(12.6)$ & Articulation, blood, CNS, & $2(22)$ \\
& & lung, nasal cavity & $1(11), 2(37), 4(1)$, \\
SC & $51(29.3)$ & Articulation, CNS, lung, & $1(1)$, NT (1) \\
& & pericardium, thoracic cavity & $7(10)$, \\
SP & $73(42.0)$ & Articulation, CNS, lung, & $1(2), 2(56), 3(10)$, \\
& & pericardium, thoracic & $7(3)$, NT (2) \\
& & cavity, peritoneum &
\end{tabular}

* PE = Pernambuco, BA = Bahia, $\mathrm{RS}=$ Rio Grande do Sul, GO = Goiás, PR = Paraná, $\mathrm{MG}=$ Minas Gerais, $\mathrm{SC}=$ Santa Catarina, $\mathrm{SP}=$ São Paulo.

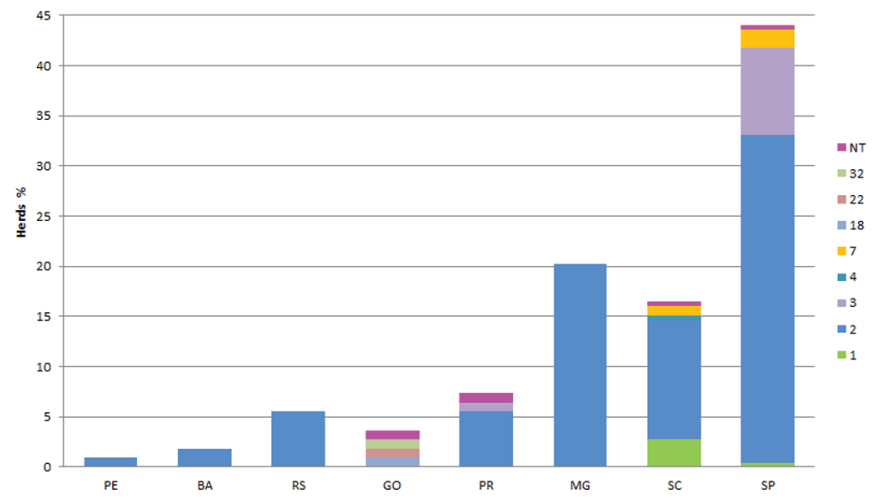

Fig.1. Percentage of Streptococcus suis serotypes according to the frequency of infected herds per State.

Table 2. Distribution of Streptococcus suis isolates according to $\mathrm{mrp} / \mathrm{epf} / \mathrm{sly}$ genotypes, serotypes and isolation site

\begin{tabular}{|c|c|c|c|}
\hline Genotype & $\mathrm{N}(\%)$ & Serotypes & Isolation Site \\
\hline$m r p+e p f+s l y+$ & $74(42.5)$ & $1,2,7$ & $\begin{array}{l}\text { CNS, arthritis, thoracic cavity, } \\
\text { blood, lung, peritoneum }\end{array}$ \\
\hline$m r p-e p f+s l y-$ & $16(9.2)$ & 2, NT & CNS, arthritis, lung, nasal cavity \\
\hline$m r p-e p f+s l y+$ & $6(3.4)$ & 2 & CNS, peritoneum \\
\hline$m r p+e p f+s l y-$ & $28(16.1)$ & $\begin{array}{l}1,2,3 \\
4,7, \mathrm{NT}\end{array}$ & CNS, arthritis, lung, nasal cavity \\
\hline mrp- epf-sly- & $20(11.5)$ & $\begin{array}{l}1,2,3,7 \\
22,32, \mathrm{NT}\end{array}$ & CNS, arthritis, lung \\
\hline$m r p+e p f-$ & $5(2$ & 2,3 & CNS \\
\hline$m r p+e p f-$ & $5(2$ & $1,2,7$ & CNS, arthritis, thoracic cavity \\
\hline$m r p+e p f v$ sly+ & $17(9.8)$ & 2 & CNS, arthritis \\
\hline$m r p-e p f-s l y+$ & $3(1.7)$ & 18 & Lung \\
\hline
\end{tabular}

$\overline{\mathrm{CNS}}=$ Central nervous system, $\mathrm{NT}=$ non-typeable. 


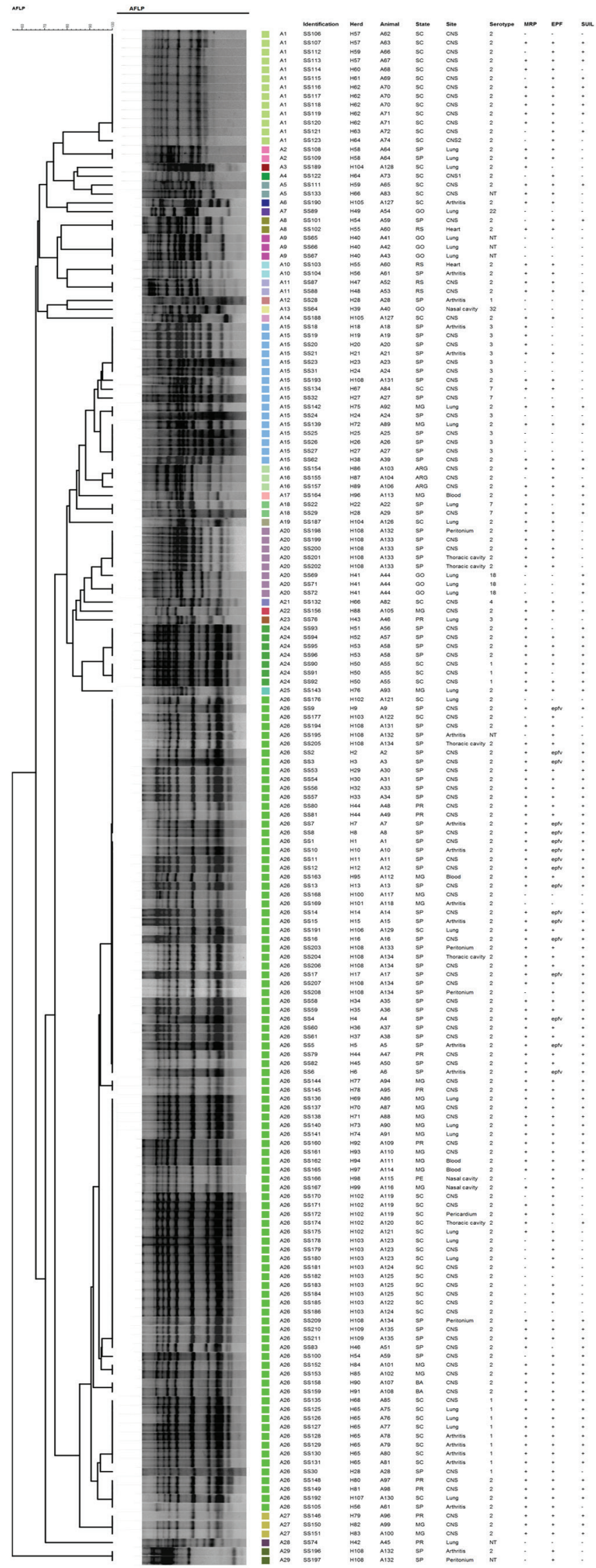

Fig.2. Dendrogram showing the relationship among the Streptococcus suis isolates SE-AFLP patterns. dency to cluster according to serotype and origin; however, no further correlation with virulence genotypes was observed.

Interestingly, only 17 strains from São Paulo State belonging to serotype 2 presented the $\mathrm{mrp}^{+} / \mathrm{epfv} / \mathrm{sly}^{+}$genotype. They were isolated from articulation and central nervous system of distinct animals from 17 herds. These isolates presented high genetic similarity and clustered at profile A26 (composed by 92 strains), together with strains from serotype 1 and presenting different virulence genotypes.

The high frequency of $S$. suis serotype 2 isolation, especially from the central nervous system, corroborates previous studies of swine infection in Brazil and worldwide (Pagnani et al. 2002, Vela et al. 2003, Del'Arco et al. 2008, Rocha et al. 2012). Also the high frequency of $\mathrm{mrp}^{+} / \mathrm{epf}^{+} /$ sly $^{+}$and $\mathrm{mrp}^{+} / \mathrm{epfv} / \mathrm{sly}^{+}$genotypes corroborates previous reports of $S$. suis infection in Europe and China (Silva et al. 2006, Wei et al. 2009).

The epf gene variation with higher molecular weight appears to be a characteristic of Brazilian S. suis serotype 2 as previously described by Martinez et al. (2003). The high genetic similarity observed for these isolates suggest that the epf variation may be correlated with more intrinsic genetic characteristics of $S$. suis that is worthy of further studies. Moreover, these isolates were obtained from diseased animals contradicting the statement that EF variant strains are weakly virulent (Vecht et al., 1992).

\section{CONCLUSIONS}

This is the first assessment of Brazilian Streptococcus suis isolation throughout a five-year period and genotypic analysis of strains of various serotypes and different origins.

These results are essential to the establishment of $S$. suis epidemiology throughout the country and its application for the disease management.

The knowledge of serotypes frequency is highly valuable for the development of S. suis vaccines.

Acknowledgements.- This study was supported by FAPESP (Fundação de Amparo a Pesquisa do Estado de São Paulo) project 2015/26159-1, CAPES (Coordenação de Aperfeiçoamento de Pessoal de Nível Superior) and CNPq (Conselho Nacional de Desenvolvimento Científico e Tecnológico) project 309062/2014-4.

\section{REFERENCES}

Boom R., Sol C.J.A. \& Salimans M.M.M. 1990. Rapid and simple method for purification of nucleic acids. J. Clin. Microbiol. 28:459-453.

Del'Arco A.E., Santos J.L., Bevilacqua P.D., Faria J.E. \& Guimarães W.V. 2008. Swine infection by Streptococcus suis: a retrospective study. Arq. Bras. Med. Vet. Zootec. 60:878-883.

Gottschalk M., Segura M. \& Xu J. 2007. Streptococcus suis infections in humans: the Chinese experience and the situation in North America. Anim. Health Res. Rev. 8:29-45.

Gottschalk M., Higgins R., Jaques M., Mittal K.R. \& Henrichsen J. 1989. Description of 14 new capsular types of Streptococcus suis. J. Clin. Microbiol. 27:2633-2636.

Goyette-Desjardins G., Auger J.P., Xu J., Segura M. \& Gottschalk M. 2014. Streptococcus suis, an important pig pathogen and emerging zoonotic agent: an update on the worldwide distribution based on serotyping and sequence typing. Emerg. Microb. Infect. 3:e45. Doi:10.1038/emi.2014.45 
Jacobs A.A., Loeffen P.L., Van den Berg A.J. \& Storm P.K. 1994. Identification, purification and characterization of thiol-activated hemolysin (suilysin) of Streptococcus suis. Infect. Immun. 62:1742-1748.

King S.J., Heath P.J., Luque I., Tarradas C., Dowson C.G. \& Whatmore A.M. 2001. Distribution and genetic diversity of suilysin in Streptococcus suis isolated from different diseases of pigs and characterization of the genetic basis of suilysin absence. Infect. Immun. 69:7572-7582.

Martinez G., Pestana de Castro A.F., Ribeiro Pagnani K.J., Nakazato G., Dias da Silveira W. \& Gottschalk M. 2003. Clonal distribution of an atypical $\mathrm{MRP}+, \mathrm{EF}^{*}$, and suilysin+ phenotype of virulent Streptococcus suis serotype 2 strains in Brazil. Can. J. Vet. Res. 67:52-55.

McLauchlin J., Ripabelli G., Brett M.M. \& Threlfall E.J. 2000. Amplified fragment length polymorphism (AFLP) analysis of Clostridium perfringens for epidemiological typing. Int. J. Food Microbiol. 56:21-28.

Okwumabua 0., O'Connor M. \& Shull E. 2003. A polymerase chain reaction (PCR) assay specific for Streptococcus suis based on the gene encoding the glutamate dehydrogenase. FEMS Microbiol. Lett. 218:79-84.

Pagnani K.J.R., Castro A.F.P., Gottschalk M., Silveira W.D. \& Nakazato G. 2002. Sorotipagem de amostras de Streptococcus suis isoladas de suínos em granjas dos estados de São Paulo, Minas Gerais e Paraná. Pesq. Vet. Bras. 22:1-5.

Rehm T., Baums C.G., Strommenger B., Beyerbach M., Valentin-Weigand P. \& Goethe R. 2007. Amplified fragment length polymorphism of Streptococcus suis strains correlates with their profiles of virulence-associated genes and clinical background. J. Med. Microbiol. 56:102-109.
Rocha D.L., Santos L.F., Santos D.L., Costa W.M.T. \& Santos J.L. 2012. Sorotipos de Streptococcus suis identificados em suínos com meningite no estado do Paraná. Arq. Bras. Med. Vet. Zootec. 64:488-490.

Silva L., Baums C.G., Rehm T., Wisselink H., Goethe R. \& Valentin-Weigand P. 2006. Virulence-associated gene profiling of Streptococcus suis isolates by PCR. Vet. Microbiol. 115:117-127.

Van Belkum A., Tassios P.T., Dijkshoorn L., Haeggman S., Cookson B., Fry N.K., Fussingg V., Green J., Feil E., Gerner-Smidt P., Brisse S. \& Struelens M. 2007. Guidelines for the validation and application of typing methods for use in bacterial epidemiology. Clin. Microbiol. Infect. 13:1-46.

Vecht U., Wisselink H.J., van Dijk J.E. \& Smith H.E. 1992. Virulence of Streptococcus suis type 2 strains in newborn germfree pigs depends on phenotype. Infec. Immun. 60:550-556.

Vela A.I., Goyache J., Tarradas C., Luque I., Mateos A., Moreno M.A., Borge C., Perea J.A., Dominguez L. \& Fernandez-Garayzabal J.F. 2003. Analysis of genetic diversity of Streptococcus suis clinical isolates from pigs in Spain by pulsed-field gel electrophoresis. J. Clin. Microbiol. 41:2498-2502.

Wei Z., Li R., Zhang A., He H., Hua Y., Xia J., Cai X., Chen H. \& Jin M. 2009. Characterization of Streptococcus suis isolates from the diseased pigs in China between 2003 and 2007. Vet. Microbiol. 137:196-201.

Wisselink H.J., Smith H.E., Stockhofe-Zurwieden N., Peperkamp K. \& Vecht U. 2000. Distribution of capsular types and production of muramidase-released protein (MRP) and extracellular factor (EF) of Streptococcus suis strains isolated from diseased pigs in seven European countries. Vet. Microbiol. 74:237-248. 